\title{
0 trabalho das meninas: um estudo através das gerações
}

\author{
Joel Orlando Bevilaqua Marin*
}

\begin{abstract}
Resumo: A pesquisa analisa os processos de inconporação das meninas no trabalho doméstico e agrícola, a partir da experiência de três gerações diferentes. O trabalho das meninas sempre esteve orientado para a preparação dos papéis da mulher como reprodutora, no sentidb biológico e sociceconômico. Fica claro que, nas sucessivas geraçães, as meninas suportaram a exploração do trabalho em decorrência do fato de serem crianças e do sexo feminino.
\end{abstract}

Palavras-chave: trabalho infantil; gênero; Goiás.

\section{Introdução}

A riès, em História social da criança e da família, lançou a tese de que a infância é uma construção social, cujas representações e práticas infantis sofreram mudanças consideráveis na passagem da sociedade medieval para a formação social burguesa. Em oposição à educação medieval, que ensinava os saberes e as técnicas usuais no convívio com os adul tos, a burguesia estimul ou a escolarização como uma forma de preparar as crianças para que elas pudessem interagir com os adultos. A criança passou então a ser vista como um adulto em gestação. Concomitantemente, a família também passou por transformações consideráveis com o desenvolvimento dos valores da vida privada e do foro íntimo, as quais repercutiram na supervalorização da criança.

B erger \& L uckmann (1997), por sua vez, no estudo sobre os processos de "construção social da realidade", afirmam que, na socialização primária, a criança experimenta os primeiros referenciais sociais necessários para se integrar à sociedade. A ssim, as experiências

\footnotetext{
* Professor da Universidade Federal de Goiás. E-mail: marin@ agro.ufg.br
}

vividas posteriormente são apreendidas com base nas primeiras, que estruturaram as maneiras de pensar e agir do indivíduo. $\mathrm{N}$ a continuidade da interiorização da realidade, a socialização secundária introduz o indivíduo já socializado em processos subseqüentes do mundo objetivo de sua sociedade. Desse modo, o aprendizado da vida em sociedade não se real iza natural mente, uma vez que a inculcação das regras sociais necessita da intervenção de diversas instâncias sociais que concorrem para a concretização do processo de socialização das crianças.

A transformação em um ser social implica a interiorização da realidade e, para tanto, tornase necessário aprender a desempenhar certos papéis decorrentes das condições de classe social e de gênero. A questão de classe social adquire importância na medida em que situa os indivíduos na estrutura econômica, na divisão social do trabalho e no conjunto das representações sociais. A questão de gênero também assume significados sociais porque a posição ocupada pelo indivíduo dentro da família, da classe social e da sociedade depende, em grande medida, do que é estabel ecido como específico para os homens e para as mulheres. Ou seja, cada indivíduo deve identificar-se com as atri- 
buições sociais próprias de seu sexo, em contraposição com o que se interioriza como próprio do sexo oposto. Todavia, para não cair em generalizações que distorcem a compreensão da realidade social, impõe-se especificar as condições econômicas, sociais e culturais objetivas da população em estudo.

Como afirma B ourdieu (1998), a história de al gum indivíduo pode ser entendida como uma "variante estrutural" do habitus de seu grupo ou de sua classe social. 0 habitus tende a conformar e a orientar a ação do indivíduo, porém, na medida em que é produto das relações sociais, ele tende a reproduzir essas mesmas relações objetivas que o originaram. A interiorização dos valores, normas e princípios sociais assegura a adequação entre as ações dos atores e a realidade objetiva como um todo. A ssim, o habitus se refere tanto ao individual como ao social (grupo ou classe), pois o processo de interiorização implica a internalização da objetividade, que ocorre de forma subjetiva, mas não se situa exclusivamente no domínio da individualidade.

Com base nesses pressupostos, este artigo anal isa os processos de incorporação das meninas no trabalho doméstico e agrícola, a partir das experiências de vida de três gerações diferentes. A pesquisa se fundamentou em uma metodologia do tipo estudo de caso, sendo os dados de campo levantados no município de I taberaí, estado de Goiás. A primeira situação procura reconstruir os processos de integração das meninas nos trabalhos agrícolas e domésticos, realizados no interior de famílias que tinham a agricultura em pequena escala como sua principal atividade produtiva. 0 ponto de partida é o estudo das experiências de vida de mulheres que hoje contam com mais de 65 anos de idade, a fim de resgatar as vivências de suas infâncias. A segunda situação busca compreender os processos de socialização das meninas que sofreram, direta ou indiretamente, a modernização da agricultura, o êxodo rural e a adaptação ao modo de vida nas periferias da cidade. A análise, nesse caso, prioriza a experiência das mulheres trabalhadoras, com idade entre $30 \mathrm{e}$ 45 anos, moradoras de vilas periféricas e que vivenciaram - ou vivenciam - o trabalho infantil em suas famílias. Na última situação, calcada no problema atual, o interesse se centrou na socialização de meninas com idade entre 7 e 14 anos, que se incorporaram no mercado de trabaIho e que atualmente são beneficiárias dos programas de combate ao trabal ho infantil, instituídos pelo governo, desde o final da década de 1990.

A técnica de pesquisa utilizada foi a entrevista semi-estruturada. No caso das meninas que participam de programas de combate ao trabalho infantil, as entrevistas foram realizadas em grupos, na escola ou nos espaços reservados para a jornada ampliada, com anuência das meninas, dos professores e dos orientadores. Para complementar as informações, na escola foram aplicadas redações com o tema "M eu trabal ho", conforme orientações metodológicas de W hitaker (1990).

\section{0 trabalho das meninas camponesas}

A partir do final da década de 1940, no contexto da política da M archa para o Oeste, muitos camponeses, oriundos de M inas G erais, São Paulo e de diversos estados do Nordeste, chegaram a Goiás em busca de terra para trabal har e reconstruir suas vidas nessa região de fronteira. Valendo-se do trabalho de seus familiares, esses camponeses passaram, então, a desenvolver uma produção agrícola e/ou pecuária diversificada, em pequenas extensões de terra, em que cultivavam diversos gêneros necessários ao consumo familiar, destinando à comercialização somente os excedentes da produção. Com os parcos recursos obtidos nessas vendas, eles adquiriam bens de que não dispunham em suas unidades produtivas. A Iguns camponeses conseguiram ter a propriedade legal de um pequeno lote de terra; outros, os posseiros, tinham a posse de pequenas extensões de terra, mesmo sem ter o título legal da propriedade. Os parceiros e os arrendatários, por sua vez, tinham a concessão temporária de uso de uma faixa de terra para trabalhar, com a condição de pagar um percentual da renda, em dinheiro ou em produto, conforme o acordo estabel ecido com os fazendeiros.

Os camponeses apresentavam especificidades não apenas nas formas de organizar a produção e a reprodução social, mas também nas várias expressões dos rituais religiosos, da 
culinária, do folclore, do artesanato, do lazer e das formas de integração das crianças no mundo adul to. 0 modo de vida próprio do campesinato manifestava-se ainda nos processos de socialização das meninas na família e na sociedade.

De maneira geral, a família dos camponeses de Itaberaí era nuclear, isto é, composta pelo casal e filhos solteiros. A estrutura das famílias dos camponeses obedecia a uma hierarquia, na qual a autoridade maior era do pai, chefe da família, que assumia a responsabilidade pela família e pela organização dos espaços produtivos. N esse papel, ele provinha os recursos necessários à manutenção do grupo familiar, tomava as decisões no âmbito do trabalho e dos negócios, além de orientar e determinar a função de cada indivíduo no interior da família.

As mulheres trabalhavam no espaço de casa e de seu entorno. Limpavam a casa, preparavam os al imentos, cuidavam dos filhos, dos doentes e dos animais domésticos, faziam a transformação caseira dos produtos agropecuários, fiavam e teciam o al godão, confeccionavam roupas. Nos momentos em que havia maior demanda de mão-de-obra, trabalhavam na roça, ao lado dos homens, às vezes executando as mesmas tarefas. Esse trabalho, porém, era considerado apenas uma "ajuda", um complemento ao conjunto das atividades da unidade de produção. A vida da mulher, portanto, só ganhava significado no âmbito da família e nas restritas relações vicinais; sua presença fora de casa era controlada, e suas relações com 0 mercado, pouco consentidas:

A ntigamente a mulher vivia debaixo do pé de chinelo do homem. Era muito triste assim, uai! Depois que casou, para sair, a mulher só saía se fosse com o marido. [...] Viajar não podia, não. Eu lembro muito que, quando tinha umas galinhas no terreno, e, se fosse para vender os frangos, eu tinha que saber dele [do marido] quantos eu podia vender, qual o preço que eu podia fazer. (A posentada, dona de casa, 78 anos)

Reconhecia-se que o pai e a mãe eram os principais agentes socializadores dos filhos, porém, quando eles não conseguiam cumprir sua missão de educadores dos filhos, seja em casos de morte, doença mental, abandono do lar, seja por invalidez para o trabalho, a comunidade solidarizava-se com as crianças, tomando-as sob sua guarda para dar continuidade ao processo de socialização. A ssim, as crianças desamparadas passavam a circular entre as famílias de tios, padrinhos, avós, vizinhos e amigos, recebendo em troca abrigo, al imentação, vestuário e uma educação, senão escolar, pelo menos em termos de sociabilidade, o que as livrava do abandono:

\begin{abstract}
Quando a minha mãe morreu, nós ficamos lá na casa do meu pai. M as el e não cuidava, aí virou aquel a pereba: a gente ficava só brincando, não cuidava do corpo. Aí uns falaram assim: "Gustinho, traz essa menina pra ficar comigo". [...] A i eu fui para G oiás e as outras [três] irmãs vieram para I taberaí. [...] Nós nunca tivemos o gosto de morar juntas. Ficava tudo assim, um pouco na casa de um, um pouco na casa de outro. Uns zelava de nós. Aí nós fomos crescendo, tivemos mais idéias e fomos zelando mais do corpo. $M$ as sempre teve que trabalhar na roça: eu e minhas irmãs pegava na roça para juntar cisco, outras vezes capinava e trabal hava na casa. A gente pegava para poder comprar roupa para nós, se quissesse vestir uma roupa mais ou menos. Era assim porque o meu pai não dava não. (A posentada, dona de casa, 65 anos)
\end{abstract}

A fora situações excepcionais, a função educativa das crianças era atribuição social dos pais. Contudo, parte dos cuidados dos irmãos menores era transferida, principalmente, para 0 encargo da irmã mais velha, que assumia um papel de segunda mãe. Ela era incumbida de cuidar, educar, vigiar e punir os irmãos mais novos. Em compensação, os irmãozinhos the deviam respeito e obediência. Q uando isso não acontecia, os pais intervinham no sentido de reforçar o reconhecimento da autoridade da irmã mais vel ha sobre os mais novos:

A autoridade da irmã mais vel ha sempre teve. A gente sofria mais que da mãe. 0 irmão mais velho e a irmã mais velha sempreeram elogiados para dominar os mais novos. Essa minha irmã vive atéhoje eela me dominava mesmo ejudiava e queria sempre bater na gente. $E$ até hoje a gente obedece ela. (A posentada, dona de casa, 67 anos) 
A creditava-se que o regime fundamentado na obediência às normas estabel ecidas, seja em casa, seja em sociedade, ensinaria as crianças e os jovens a assumir, prematuramente, comportamentos responsáveis. A ssim, a educação das crianças na família era marcada pela austeridade dos adultos, e toda falta deveria ser corrigida com castigo físico, com intimidação moral ou com depreciações. Os pais e os adultos acreditavam que surravam, não por mal dade, mas por amor às crianças. Pressupunham que a punição fisica era um recurso de educação para instruílas e dirigi-las ao necessário desenvolvimento do senso de responsabilidade e obediência à autoridade dos adultos. M as os castigos reduziam-se, na medida em que elas tornavam-se submissas e aprendiam a se comportar respeitosamente. A mulher adulta era considerada referência, restando às meninas repetir suas atitudes e concepções, num ciclo de disciplinarização das mentes e dos corpos infantis. $\mathrm{N}$ esse processo, as idéias, as vontades e os sonhos das meninas eram desconsiderados, para dar espaço à rotina dos ordenamentos adultos:

$N$ aquele tempo a gente era tão inocente que a gente nem pensava. Tinha que fazer as coisas que os pais queriam, uai! [...] A h, se minha mãe batia em mim, eu ia fazer mesmo do jeito que ela dizia. Com meus filhos também foi assim. M eus filhos nunca falaram: "- Uai, a senhora me bateu e eu não vou fazer isso, não". [Eles] seguiam a vida do jeito que os pais queriam. (A posentada, dona de casa, 72 anos)

No processo de socialização dos filhos, 0 padrão de comportamento exigido para as meninas diferenciava-se daquele aceito para os meninos. Enquanto el es tinham mais estímulos para o exercício de posições de comando para que futuramente se tornassem chefes de família, elas eram educadas para manter uma conduta de recato, pudor e abnegação. Desde muito pequenas, as meninas eram socializadas numa teia de relações que privilegiavam e reproduziam valores de submissão e subalternidade, não apenas aos de casa, mas também aos parentes e vizinhos. A s moças eram mantidas nos trabaIhos do lar, quando necessário na roça, e não Ihes era permitida manutenção de muitas e estreitas amizades com pessoas do sexo oposto, que não os da própria família ou da parentela. 0 círculo de relações das moçoilas era restringido e a participação nos espaços públicos era algo temido pelos pais e, quando isso acontecia, a vigilância aumentava:

Nós quase nunca passeava. M inha mãe não deixava a gente sair de casa. Tinha que ficar quieta em casa. N ossa, ir a uma festa ou a uma missa? Nunca que ia, de jeito nenhum! Era difícil! Se tivesse achando bom, ficava quieta; se achasse ruim, ficava a mesma coisa. (A posentada, dona de casa, 76 anos)

No convívio familiar, repassavam-se e recebiam-se os principais ensinamentos necessários à vida, daí o ditado popular: "A casa dos pais é a escola dos filhos". A infância era a fase da vida mais adequada para o aprendizado essencial do trabalho e dos principais conhecimentos e significados do modo de vida camponês. Ensinar significava repassar valores, normas, modos de pensar e de fazer, cujos significados eram reafirmados e reproduzidos em todas as conversas, ações e interações sociais. A través da observação e do ensaio, pouco a pouco, as meninas reproduziam os gestos e movimentos do corpo da mãe e das irmãs mais vel has no trabalho (M arin, 2005).

A inda sem poder andar com as próprias pernas, algumas crianças já eram carregadas pelas suas mães para o trabalho. A necessidade de prover 0 sustento familiar impunha-se inexoravelmente aos pais, que, desprovidos de condições favoráveis, levavam consigo seus filhos para o trabalho. Sem opção de escolha, as crianças acabavam permanecendo nas proximidades dos locais de trabal ho dos adultos, introjetando os principais hábitos e saberes necessários ao modo de vida dos camponeses. M esmo sem ter consciência do mundo ao seu entorno, desde pequeninas aprendiam a adiar a hora das refeições, a suportar a fome, o calor, 0 frio, a chuva, a poeira. Enfrentavam, assim, um difícil processo de disciplinarização do corpo e da mente para uma vida marcada pelo peso do trabalho:

Eu não tinha um ano de idade e minha mãe já me levava para a roça. Eu ficava debaixo do pé de café para ela poder apanhar o café para 
ganhar dinheiro. Ela levava umas cobertas, umas coisas lá e punha eu. A minha vida foi sofrida desde pequenica. (A posentada, 86 anos)

Q uando adqui riam o controle suficiente das pernas e podiam usar os braços e mãos, as crianças eram conduzidas a partilhar do trabalho junto aos adultos. Daí por diante, as diferenças na educação e no trabalho passavam por progressivas alterações: os meninos conviviam e trabalhavam mais próximos do universo masculino, enquanto as meninas já eram, de certo modo, incorporadas aos trabal hos da casa, do quintal, ao cuidado dos irmãos menores, junto à mãe e às irmãs.

A passagem dos 7 para os 8 anos era considerada importantíssima, pois nessa idade as crianças começavam a tomar consciência da vida e do mundo. As meninas recebiam, então, maior quantidade de ensinamentos e tarefas voltados aos serviços domésticos, enquanto os meninos eram dirigidos, prioritariamente, aos trabalhos fora da casa, na lavoura e no trato dos animais, acompanhando os homens da casa. Vale ressaltar que não havia uma divisão sexual do trabal ho muito rígida, uma vez que as meninas e os meninos tornavam-se uma espécie de trabal hadores pol ival entes, atuantes dentro efora de casa, conforme as determinações dos adultos.

Seguindo uma certa divisão sexual do trabal ho no interior da família, elas eram orientadas para 0 aprendizado de determinados serviços domésticos, tais como: providenciar alguns alimentos, lavar roupas e vasilhas, arrumar a casa, varrer o pátio, buscar na bica ou no poço a água de uso doméstico, fazer doces, fabricar farinha de mandioca, pilar arroz, costurar e remendar roupas, fiar e tecer algodão, fazer tricô e crochê, cuidar dos irmãos pequenos, zelar da horta e dos animais. 0 aprendizado dessas tarefas era um processo contínuo, progressivo, no qual, por meio do fazer, aprendiase a trabalhar. $\mathrm{Na}$ convivência junto à mãe ou ao lado das irmãs mais velhas, as meninas naturalmente incorporavam os hábitos e os conhecimentos julgados apropriados às mulheres. M as 0 aprendizado das meninas não se restringia aos serviços domésticos, porque saber trabalhar nas lidas da roça também era consi- derado importante. Dependendo da demanda de mão-de-obra para os serviços da lavoura, as meninas também contribuíam no somatório de braços, sem, com isso, serem dispensadas dos trabal hos domésticos:

Eu fazia de tudo para a minha mãe: lavava vasilha, roupa, fazia comida e limpava a casa. $M$ inha mãe criou dezesseis filhos e nunca pôs uma pessoa para trabal har com ela. Quem fazia as coisas para ela era só eu e ainda ia para a roça. Se não agüentava capinar, arrancava com a mão e tirava os matos. Quando era a época de colheita, a gente ia cortar arroz com cutelo, apanhava milho, arrancava feijão, fazia de tudo. (A posentada, dona de casa, 78 anos)

A participação das meninas no mundo do trabal ho acontecia progressivamente, na medida do seu crescimento físico, da posse de conhecimentos, da mobilidade e da habilidade corporal no manuseio dos instrumentos de trabalho. Pouco a pouco, elas passavam a executar os mesmos trabalhos e, por extensão, a adotar 0 comportamento das mulheres adultas. A habilidade e a coragem na execução de tarefas mais complexas eram sempre elogiadas pelos adultos, como forma de incentivar 0 desenvolvimento pessoal e a boa vontade para o trabal ho. A ssim, as meninas cresciam entre os adultos, aprendendo que era apenas na dura labuta cotidiana que se garantia a sobrevivência no contínuo ciclo plantar-cultivar-colher os alimentos. E que do trabalho não dependia só a alimentação, mas também o vestuário feito com fibras de al godão fiadas e tecidas a mão, o abrigo da moradia revestida de barro, sustentada por esteios retirados das matas e coberta com folhas de palmeiras trançadas, a produção de óleo de mamona para iluminar as residências e a produção de ervas medicinais para resolver os problemas de saúde.

0 trabalho da menina era categorizado como "ajuda", porque era considerado leve e educativo. Essa categorização era mais uma construção social que servia de argumento comumente usado não só para desqualificar a mão-de-obra de quem o realizava, mas também para justificar os baixos preços dos produtos finais e, conseqüentemente, a baixa remuneração dessa força de trabal ho (Paulilo, 1987). 
A crescente transferência do peso do trabaIho às meninas encurtava o período de inserção no mundo do adulto, entendido como o mundo do trabalho, e tornava a infância uma idade da vida de maiores responsabilidades e de menor dependência em relação aos adultos. A 0 atingirem os 12 ou 13 anos de idade, dizia-se que el as estavam tornando-se "mocinhas". Essa fase da vida era muita abreviada e significava muito mais carga de trabalho e atitudes responsáveis no interior da família e perante a sociedade. Não se admitiam contestações das mocinhas. CabiaIhes comportar em conformidade com o mundo das adultas, além de mostrar discernimento próprio das situações que as cercavam. Isso significa que elas deveriam saber fazer todas as atribuições relativas ao seu sexo, para logo assumirem a responsabilidades de suas próprias famílias. Desse modo, o casamento marcava sua independência em relação aos pais e a constituição de uma nova família e unidade de produção. Todavia, o casamento não interrompia as atividades produtivas da jovem, mas somente mudava a unidade de produção em que seinseria: de "trabalhadora ajudante" do pai passava a "trabal hadora ajudante" do marido.

A prioridade dos ensinamentos práticos proporcionado pelo trabal ho cotidiano afastava as meninas da escola. M ais do que isso, as meninas tinham menos direitos sociais ao estudo, pois, quando a família pensava em proporcionar um pouco de escolarização a algum dos filhos, a prioridade recaía sobre os meninos. Os dados do IBGE do ano de 1940 indicam que havia no município de I taberaí um total de 14.734 pessoas com mais de seis anos; destes, 7.311 eram mul heres e 7.423 eram homens. Entre as mulheres apenas $13,2 \%$ eram alfabetizadas, enquanto entre os homens o índice de alfabetização era um pouco melhor, em torno de 22,9\%. 0 Censo de 1950 aponta que as famílias continuaram priorizando a escolarização das pessoas do sexo masculino: de um total de 6.705 homens, com mais de seis anos, 30,38\% foram alfabetizados e, dentre as 5.824 mulheres na mesma faixa etária, somente $24,55 \%$ receberam um mínimo de escolarização.

Os adultos não percebiam qualquer razão para que as meninas adquirissem fora de casa conhecimentos úteis aos papéis de esposa, mãe e dona do lar. Dizia-se que o mais importante na vida das mulheres era o repertório do saber cozinhar, lavar, cuidar dos filhos e do quintal, um aprendizado para o qual a escola em nada colaboraria. A demais, a escola era percebida como "local de perdição" das moças, pois, como ditavam os mais velhos, "mulher saber ler e escrever não é virtude". A creditava-se que elas ficariam mais "abusadas", escreveriam "bilhetinhos" para os namorados e, rompendo com as convenções sociais estabelecidas, acabariam por "sujar o bom nome da família".

De maneira geral, as meninas eram muito discriminadas e reprimidas quando freqüentavam a escola, em razão das relações de força e autoridade que estavam estruturadas, não apenas na família ou na relação professor-aluno, mas também entre os alunos. N essa correlação de forças, os mais velhos e fortes sobrepunham-se aos mais novos e fracos, e os meninos sobre as meninas. Socializadas para a resignação e para a submissão ao universo masculino, muitas meninas sofriam tantas humilhações na escola que acabavam preferindo retornar ao trabalho:

Eu chegava lá na escola, aquelas bobas, sabe? Os meninos batiam na gente, e eu ficava quieta. Se a gente era custosa, eles batiam. E se não era, batia também. Por causa del es verem a gente muito boba lá no canto, eles batiam também. B atiam em qual quer um. N ossa! Eu tomava cada croque na cabeça! A h, meu Deus, eu chorava era quietinha ali. N ossa Senhora, eu chorava tanto, eu sofria calada. A té hoje eu sofro calada. Aí eu fui embora para Goiás Velho e fiquei trabalhando na casa de uma mulher. (A posentada, dona de casa, 66 anos)

Em Itaberaí, existiam poucas escolas para crianças. A maioria delas estava estabelecida na sede do município ou nos distritos mais habitados. A população que vivia espalhada pelas roças tinha dificuldade em colocar seus filhos nas escolas, uma vez que necessitava pagar aluguel em casas da cidade, comprar roupas e materiais escolares. A lém do mais, a grande maioria dos camponeses, com muitos filhos, não podia arcar com esses gastos:

Meu pai falou assim: "Olha, mais adiante a gente vai arrumar um jeito de pôr um professor em casa. É que agora não tem jeito de vocês 
saírem, porque não posso pagar um lugar para vocês ficarem em casa al heia. Para ficar em casa al heia é muito difícil, fica muito custoso. Então, é melhor ficar em casa e, mais adiante, a gente põe um professor em casa, na hora que a gente tiver melhor condição de pagar um professor". Só que esse tempo nunca chegou e nunca chegou a nossa vez de estudar. (A posentada, dona de casa, 76 anos)

A lém do custo el evado, os estudos escolares implicavam prescindir do trabal ho da criança, pelo menos temporariamente. $\mathrm{No}$ balanço das vantagens e desvantagens da escola - e, em face das carências das famílias -, os pais preferiam que suas filhas permanecessem em casa trabal hando. A fora a falta de condições materiais de existência, a dispersão demográfica da população rural, a falta de mobilidade espacial dessa população, os problemas de saúde na família, a baixa qual idade do ensino ministrado, o desestímulo do professorado e a ignorância dos pais para compreender a necessidade da escola na vida das meninas contribuíam para a manutenção dos bai xos índices de escolarização. Deve-se acrescentar também que os camponeses não valorizavam a escola porque viviam no âmbito de uma economia de excedentes, marcada por um processo produtivo orientado para a produção de bens de uso, com a comercialização apenas de parte da produção. Como os camponeses estavam envolvidos em relações sociais que priorizavam os contatos pessoais para o intercâmbio de bens e serviços, os conteúdos repassados pela escola assumiam pouca importância e as aspirações em relação à escola estavam associadas apenas a ler, a escrever e a fazer as contas (M artins, 1981).

Enfim, a infância das meninas camponesas de Itaberaí era marcada pelo trabalho e pela indispensável contribuição que cabia a cada indivíduo da família para suprir as difíceis condições de vida. 0 trabal ho era o fio que tecia todas as existências das pessoas, da infância à velhice, e exigia que os corpos ainda infantis se dobrassem ante o trabalho, posto como o único meio capaz de suprir os bens necessários a cada dia, bem como o mei o fundamental para a existência de todos os indivíduos. A infância era um tempo de aprendizado do trabalho e no trabalho, restando pouco tempo à brincadeira:
No meu tempo, não tinha jeito de cuidar de uma brincadei rinha, porque de domingo tinha o que fazer. Nos dias de semana tava trabaIhando e nos dias de sábado e domingo tinha tempo para pilar arroz, catar feijão, lavar roupas, arrumar as coisas e deixar tudo pronto para durante a semana fazer a comida. De segunda a domingo começava de madrugada e terminava à noite. Não tive tempo para brincadeira. M inha vida sempre foi corrida e é até hoje. (A posentada, dona de casa, 78 anos)

Isto não quer dizer que as crianças não vivenciavam situações lúdicas enem mesmo que o aprendizado do trabal ho deixava de ter seus encantamentos. As meninas brincavam com as bonecas confeccionadas por elas próprias, usando retalhos de pano ou mesmo improvisando-as com abóboras e espigas de milho. B astante comum entre elas era brincar de "cozinhadinho", que consistia em preparar pequenas porções de alimentos, em panelas de barro, para posterior degustação. B rincando de costurar, de cozinhar e de cuidar de bonecas, ao mesmo tempo, as meninas desenvolviam habilidades e saberes que Ihes seriam necessários em seu papel de futuras donas de casa. Às crianças contavam-se muitas estórias e causos do passado. Em uma sociedade de tradição oral, em que poucos sabiam escrever, essas estórias e causos faziam parte do repertório social izante e, ao mesmo tempo, lúdico, não só das crianças sertanejas, como também dos adultos.

\section{0 trabalho de meninas migrantes no campo e na cidade}

A década de 1960 ficou marcada pela modernização da agricultura, processo que estrei tou os víncul os de interdependência entre os setores agrícolas e industriais. 0 setor agrícola se interligou com os setores da indústria de produção de máquinas, equipamentos e insumos modernos, da indústria de transformação de alimentos, além dos setores financeiros e comerciais, constituíndo os complexos agroindustriais. A ssim, a agricultura se integrou à lógica da expansão capitalista, que resultou em profundas transformações tecnológicas, especialmente pela incorporação de máquinas, de insumos agrícolas e de novos procedimentos técnicos, 
redefinindo o papel da agricultura no conjunto das atividades econômicas do país. No contexto da pol ítica desenvol vimentista, com ampla abertura para o mercado estrangeiro, a Região Centro-Oeste tornou-se uma área prioritária para a expansão da agricultura nacional. Para tanto, o estado de Goiás passou a contar com vários programas especiais de desenvolvimento, que possibilitaram crédito aos empresários rurais e condições de infra-estrutura mínima para a extensão de uma rede de empresas financeiras, comerciais e industriais. No entanto, como a modernização agrícola não foi acompanhada por uma política de reforma agrária, houve um aprofundamento da concentração fundiária (Sorj, 1980).

Com a modernização agrícola, a terra tornou-se, pouco a pouco, mais valorizada e menos disponível aos camponeses. Por um lado, a partilha da terra entre herdeiros e a nãodisponibilização da terra aos arrendatários e parcei ros contribuíram para acel erar a expulsão do campo, fazendo-os migrar para a cidade, onde se instalaram nas periferias. Por outro lado, a introdução de máquinas e insumos modernos na agricultura, facilitada pelos incentivos governamentais, passou a dispensar a mão-de-obra e, ao mesmo tempo, propiciou o máximo aproveitamento dos recursos naturais. A té meados dos anos 70 , os arrendatários e parceiros ainda conseguiam terras para arrendar, mas 0 direito de moradia era algo que se tornava cada vez mais difícil, uma vez que os fazendeiros, receosos de que os trabal hadores adquirissem direitos, não permitiam que eles residissem na terra por mais de dois ou três anos.

A modernização da agricultura resultou na expulsão de grandes contingentes populacionais do campo e propiciou a expansão das relações de trabal ho assal ariado. Expropriado dos meios de produção, especialmente da terra, o camponês foi obrigado a vender a única mercadoria de que dispunha: sua força de trabal ho. 0 assalariamento despontou no horizonte do trabal hador - também denominado bóia-fria - como o recurso possível para garantir a própria subsistência, bem como de sua família, unidade de reprodução da força de trabalho (D'Incao, 1975).
A s transformações nas formas de produzir e de organizar as relações sociais fizeram parte de um processo que se realizou no decorrer de vários anos, de maneira que muitas meninas experimentaram o trabalho e o modo de vida camponês e depois migraram para cidades e vivenciaram o trabalho infantil assalariado. Outras experimentaram o trabal ho assalariado desde pequenas, porque sua família já havia migrado para a cidade.

A ssim sendo, as meninas que tiveram uma social ização no meio rural deviam não só adquirir as habilidades inerentes aos serviços domésticos, aos cuidados dos irmãos menores, mas também dar sua contribuição nos trabalhos da roça. Quando na composição familiar havia um desequilíbrio entre o número de homens e de mulheres, o chefe da família definia a distribuição da força de trabalho:

Eu tinha sete irmãos: dois homens e cinco mulheres. $M$ as como não tinha nenhum peão para ajudar meu pai, porque meus irmãos estavam com cinco e seis anos e eu estava grandinha, então, meu pai me levava para a roça para trabalhar junto com ele. 0 meu pai achava que eu tinha [mais] inteligência para trabalhar na roça, de enxada, do que [para] ficar em casa para minha mãe ensinar. Aí, minhas irmãs trabal havam em casa e o meu trabal ho era na roça. (Bóia-fria, dona de casa, 37 anos)

Outro relato de uma senhora, mãe de três adolescentes trabalhadores, que foi criada em uma fazenda, elucida os modos de social ização das meninas pobres, que circulavam entre as famílias:

A gente morava na fazenda, eu e uma outra amiga da minha idade. Então, menino, ela [a mulher do fazendeiro] judiava de nós demais da conta, porque, você vê, ser criado pela mão dos outros é muito triste! Ela punha nós para trabalhar desde pequenininha, sabe. A gente ia para a escola o dia que desse tempo de nós fazer os serviços. Se não desse conta daquela tarefa, não ia na escola. A fazenda era grande demais e a mulher era ruim demais. A gente levava um cacete danado quando não dava conta [do serviço]. Então até hoje eu não presto da cabeça porque a vida del a era bater na minha cabeça. Com 7 anos, eu arrumava, eu lavava, 
eu passava. Eu trabalhava de doméstica, trabal hava na roça, cozinhava para peão, levava o de comer para peão, apartava as vacas, tratava dos porcos, cuidava de tudo, sabe? A gente cuidava de tudo e era uma correria danada. A í, quando eu peguei a idade de 14 anos, eu falei: "Eu vou procurar a minha mãe". A í eu fugi da companhia deles e vim procurar a minha mãe. (D ona de casa, faxineira, 40 anos)

A infância não é relembrada apenas como um tempo de muito trabalho e castigo, mas também de fartura e diversificação de al imentos, em contraposição à carência vivenciada na atual idade, que impossibilita garantir mesa farta aos filhos. Em outros depoimentos, a fome é um espectro que marcou profundamente a infância:

Faltava comida, comia mais era peixe. 0 dia que tinha arroz, comia arroz com peixe. 0 dia que não tinha, comia só peixe porque muitas vezes aconteceu de não ter arroz em minha casa e comia só peixe. Comia outras coisas, frutas; catava frutas do mato e enchia a barriga. ( $D$ ona de casa, bóia-fria, 36 anos)

Outro fato que marcou a vida de muitas crianças foi o processo de migração do campo para a cidade, especialmente 0 momento da chegada da família, com seus pertences, ao ambiente urbano. A precariedade das condições de vida na roça, a fal ta de terra para plantar e 0 endividamento com os fazendeiros tornavamse motivos de expulsão de famílias inteiras que chegavam às cidades para tentar uma vida nova:

A ntes de mudar para cá, a gente morava na fazenda. A casa não era boa, as condições de vida não eram boas. Era um rancho de palha. M eu pai vivia em dívidas com o patrão. Não tinha serviço que fazia para quitar a dívida. A gente colhia arroz, ele pegava 0 arroz quase todo para pagar a dívida e ficava devendo. U ma coisa incrível! Diz que escravatura tinha acabado, mas até essa época não tinha acabado não... Ave M aria! Então, meu pai resolveu mudar para a cidade [...]. E aí nós chegamos aqui numa pobreza incrível. 0 pessoal que trouxe aqui para I taberaí nos deixou numa calçada... sabe? E aí..., como se diz, se vira, né? [...] Naquela noite mesmo, [o povo daqui] nos trouxe comida, roupa para nós dormir, aquela meninada pequena na calçada... Quando eu ol hei assim em volta, [...] vi as luzes na rua e achei tudo bonito, tudo diferente. Então aquilo, para mim, foi esperança de vida nova. (Dona de casa, bóia-fria, 39 anos)

$\mathrm{N}$ ão se pode ignorar que, apesar de implicar grandes cotas de sacrifícios, a migração rompia os vínculos de dependência pessoal dos fazendeiros, abria possibilidades de melhorias na qualidade de vida, criava facilidades para a educação das crianças e, às vezes, aumentava as chances de encontrar trabalho assalariado, fixo ou temporário, na cidade ou na agricultura. L ogo, as meninas se incorporavam como empregadas domésticas ou somavam na força de trabal ho assalariado na agricultura, para incrementar o rendimento familiar. $\mathrm{E}$ esse processo de grande mobilidade espacial e transição entre as atividades executadas nos espaços rural e urbano era sofrido:

Eu tinha dez anos e fui trabalhar de babá para uma senhora que tinha uma criança deficiente. Eu cuidava do nenê dela, lavava as roupas e vasilhas. A í passou o tempo, fui crescendo e voltei para a roça para capinar arroz, feijão, na arranca do feijão. A té de domingo sempre nós ajudava porque era muito filho e tinha que ajudar. Eu e as minhas irmãs trabal hava na roça e depois em casa. Em casa era rotina de lavar roupa e vasil ha, fazer comida, colocar água para dentro, porque era bica eficava longe. A gente buscava nas costas e levava para casa para a hora que chegava poder tomar banho. As mulheres saíam antes, lá pelas quatro horas, para ir ajeitando as coisas e eles saiam lá pelas seis horas. A gente só sossegava depois que todos tinham tomado banho, jantado e lavado as vasilhas. (D ona de casa, bóia-fria, 35 anos)

A intensificação do êxodo rural aumentou o número de trabal hadores que disputavam as oportunidades de trabal ho nas atividades agrícolas, no comércio, na indústria ou nos serviços. 0 rebaixamento dos salários dos trabalhadores rompeu com o frágil equilíbrio da família estruturada e hierarquizada, em torno do modelo de autoridade centrada na figura do chefe provedor. Quando este não conseguia cumprir o seu papel, em função do salário insuficiente, do emprego temporário, do desemprego ou da 
invalidez, havia a necessidade de mobilizar 0 trabal ho da mulher e das crianças, para aumentar os rendimentos familiares.

A nteriormente, o homem, como chefe de família, era considerado o provedor, e a mulher e os filhos "ajudavam" a somar esforços para intensificar a produção na lavoura. Com a expansão das relações assalariadas, esse modelo foi destruído, em virtude da individualização da força de trabalho. A o capital não interessava mais aquele trabalho organizado e controlado pelo chefe da família, mas sim pelas normas e pelos critérios estabelecidos pelos "gatos" (agenciadores de mão-de-obra), pelos fazendeiros e pelas indústrias, enfim, pelo capital. A o subordinar o trabal ho de modo real, o capital desarticulou a família, como unidade de produção e consumo, transformando-a em apenas unidade de consumo. Essa transformação resultou em mudanças profundas na unidade familiar, na medida em que o trabal ho assalariado individualizou os integrantes da família, para depois inseriIos no conjunto de trabal hadores que participam do trabal ho coletivo, individualizado e organizado por critérios racionais (M arin, 2006).

Inicial mente, na condição de chefe provedor da família, o homem teve de se assal ariar. M as, sozinho, ele não conseguiu satisfazer todas as necessidades da família, porque a vida na cidade ampliou o leque das necessidades que não poderiam ser supridas apenas com os ganhos auferidos pelo chefe da casa. Além disso, as condições de reprodução ficaram cada vez mais comprometidas com o aviltamento dos salários do chefe de família, tornando premente a inclusão do trabalho das mulheres, que tiveram de se assalariarar para contribuir para 0 sustento da família (M artinez A llier, 1975; N oronha, 1986; Silva, 1999).

A s meninas também foram atingidas pela precarização das relações de trabalho e pelo empobrecimento de suas famílias, o que as levou a assumir parte do peso do trabalho, executando tarefas dentro e fora do grupo doméstico ( $\mathrm{M}$ achado N eto, 1980). Dentro do grupo doméstico, as meninas participavam da elaboração de meios diretos para a sobrevivência da família, como, por exemplo, a preparação dos alimentos, a limpeza da casa e dos pátios e o cuidado das crianças mais pequenas.
Cabe lembrar aqui que o trabal ho assalariado na agricultura se caracterizava pela sazonalidade e rotatividade, razão pela qual os trabal hadores tinham de se deslocar até os locais onde havia of erta de trabal ho, que podia ser tanto no município, ou no seu entorno, quanto em outros estados. Diante disso, os trabalhadores adultos, homens e mulheres, saíam muito cedo de casa e retornavam ao final do dia e, não raras vezes, após sete, quinze ou trinta dias, quando os locais de trabal ho eram muito distantes. Essa ausência dos membros adultos necessariamente resul tava na transferência de responsabilidades para as crianças, especialmente para as meninas, que deviam assumir todo o fardo de conduzir os trabalhos da casa.

Se até hoje as trabalhadoras pobres não dispõem de creches públicas onde possam deixar seus filhos enquanto trabalham, pode-se imaginar a situação vivenciada na época. Como nem sempre podiam contar com a confiança e soliedariedade das vizinhas, uma vez que moravam em vilas formadas por migrantes que pouco se conheciam ou que enfrentavam os mesmos problemas, cabia às meninas zelar da casa e dos irmãos menores.

Dentro de casa, algumas meninas também elaboravam bens comercializáveis e executavam trabalhos remunerados assumidos pelos grupos domésticos, a exemplo da lavagem de roupas e da produção de artesanatos e de comestíveis. No entanto, a possibilidade de atuação no mercado informal apresentava-se restrita e intermitente, mas nem por isso deixava de ser significativa como processo educativo e de "emancipação" das meninas, na medida em que as preparava para enfrentar os problemas da sobrevivência nas cidades. Fora de casa, as meninas também eram incorporadas como empregadas domésticas, babás ou prestadoras de serviços para vizinhos ou moradores da cidade, recebendo dinheiro, comida, bens de uso e, por vezes, educação escolar. Essa socialização preparava as meninas para o exercício dos papéis sociais atribuídos às mul heres, como responsáveis pela reprodução, tanto no sentido biológico como socioeconômico. Elas eram reduzi das a uma condição de "mul her pequena" ou de "mãe menor", reforçando a necessidade do processo de formação e reafirmação dos papéis sexuais, na família e na sociedade. 
Fora do espaço doméstico, muitas meninas se agregavam nos trabalhos assalariados da agricultura da região, na tentativa de melhorar a renda familiar. Com o agravamento das condições de reprodução social dos trabalhadores assalariados, el as passaram a vender sua força de trabalho para o capital, submetendo-se a horários rígidos e realizando tarefas perigosas, insalubres e superiores às suas forças. Vale ressal tar que o trabal ho assalariado na agricultura passou a ser remunerado por tarefa ou produção, ou seja, o valor do salário tornou-se proporcional à quantidade de produtos materializados pelo trabalho ou pela quantidade de tarefas executadas. Pelo fato de o salário ser avaliado pela produtividade do trabal ho, todos os membros da família em condições físicas satisfatórias se juntavam para aumentar seus rendimentos (Gonzales \& Bastos, 1982). Diante disso, as crianças de ambos os sexos eram muitas vezes compel idas a executar um trabal ho que podia ir além de seus limites físicos, na tentativa de sempre ter de se superar, para cada vez mais aumentar sua produção e incrementar os ganhos familiares. A s crianças, então, "ajudavam" seus familiares nos trabal hos assalariados na agricultura, ao mesmo tempo em que aprendiam a val orizar o trabal ho (N eves, 1999; Marin, 2006).

0 trabalho como "ajuda" e como "aprendizado", argumentos socialmente construídos para justificar a participação da criança nas unidades de produção familiar, foi rearticulado para legitimar a vincul ação de crianças nos trabal hos em relações assal ariadas. M esmo sendo prejudicial, repetitivo e alienante, sem qualquer caráter educativo ou formativo, a meninada sempre é estimulada a executar o trabal ho "para aprender" e "para poder render mais". Passa, assim, a ser percebido como algo natural, necessário e imprescindível na socialização da criança, com vistas à preparação dos futuros trabalhadores. 0 trabal ho prematuro, antes de ser um problema, transforma-se em virtude (Gouveia, 1983). N esse sentido, os mal efícios que 0 trabal ho precoce podem causar à saúde, ao desenvolvimento físico, à continuidade da escol arização, aliados a uma baixa remuneração, são minimizados pelos pais. As meninas que conseguem através de seu trabalho ganhar al gum dinheiro para suprir al guma necessidade sentem-se importantes e valorizadas pelas famílias e pela sociedade. Essa situação se repete na atualidade, como se pode perceber no relato de uma senhora:

Para os meus filhos, eu desejo o melhor: que eles aprendessem uma profissão e para as minhas filhas que fossem boas donas de casa, cuidar das tarefas direitinho e aprender uma profissão, que é inclusive um dever. 0 meu desejo é que eles sejam sinceros, honestos, trabalhadores, porque 0 trabalho é a melhor coisa que tem na vida. (Bóia-fria, dona de casa, 40 anos)

Pelo depoimento, "aprender uma profissão" é, para as crianças, "um dever", que deve ser incutido desde muito cedo, não apenas como valor social, mas como prática, que visa à naturalização e à internalização dos usos do corpo requeridos no trabalho. Portanto, desde pequenas, as meninas foram estimuladas ao trabal ho, para aprenderem a "virar-se por conta própria". M esmo que as famílias concebam o trabal ho infantil como al go natural, as crianças, no entanto, não estão livres das várias e graves conseqüências acarretadas ao seu desenvolvimento físico e intel ectual. ${ }^{1}$

É o caso da freqüência irregular das meninas à escola. Ou seja, elas só iam à escola quando havia disponibilidade de tempo e se ausentavam quando havia premência nos trabal hos dentro ou fora do grupo doméstico. Isso desmotivava a continuidade dos estudos, um problema que se repetia em outros contextos do país, conforme Antuniassi (1983). Diante disso, a necessidade primordial era o trabal ho e não as vicissitudes da escolarização:

Quando não tinha muito trabal ho, a gente ia para a escola. Por fim, a gentelargou de mão de ir na escola, porque não tinha jeito. Só trabal hando para ajudar a minha mãe. Aí nós pegamos e saímos da aula. Nós mesmos

1. É importante observar que, não apenas no Brasil mas em diversos outros países, o trabalho infantil continua sendo percebido como uma necessidade e um valor social, condições suficientes para minimizar as repercussões nefastas na vida adulta desses trabalhadores precoces, como constataram Mendelievich (1980), Bequel \& Boyden (1990), Schlemmer (1996) e Bonnet (1998). 
quisemos sair da escola porque, para trabalhar e estudar, ficou muito difícil. H oje eu escrevo um pouquinho, não escrevo bem, mas eu escrevo. (Dona de casa, bóia-fria desempregada, 52 anos)

Vale destacar que a descontinuidade da escolarização também ocorria por problemas de doença na família, de incapacidade ou de abandono do lar pelo chefe da família, de impossibilidade de adqui rir os materiais de uso didático e, muitas vezes, da crença de que algumas meninas não tinham "boa idéia para os estudos".

Desde a década de 1940, o Estado brasileiro adotou programas de combate ao analfabetismo, a fim de formar uma população mais integrada à vida cívica do país e economicamente mais produtiva. N essa perspectiva, a educação de adultos aparecia interligada à educação das crianças e dos adol escentes, porque apenas com a alfabetização daqueles era que estes mais rapidamente poderiam educar-se. 0 s agentes estatais salientavam ainda que a melhoria do nível cultural e o aumento da produção só se realizariam, no futuro próximo, caso as crianças fossem educadas na escola (Paiva, 1987). Contudo, o Censo do IBGE de 1960 apontava que 0 índice de analfabetismo girava em torno de $60,5 \%$ da população itaberina em idade escolar. Esse mesmo censo indicava que, de um total de 7.813 crianças e adolescentes entre 6 e 14 anos existentes em Itaberaí, 2.377 freqüentavam a escola, o que representava apenas $30,4 \%$. Esses dados revelam também que, apesar dos consideráveis avanços na expansão do sistema educacional no meio rural, os resultados não eram tão animadores e as iniciativas do Estado na melhoria da educação apresentavam-se ineficazes para debelar 0 analfabetismo entre as crianças e os adolescentes.

\section{As meninas trabalhadoras assalariadas}

Em pleno século XXI, o trabal ho infantil é um problema social que continua se reproduzindo na realidade brasileira. Dada a sua gravidade, diversas instituições, nacionais e internacionais, investiram na construção de uma imagem da infância associada aos estudos, à brincadeira, ao sorriso eà inocência - condições indica- doras de uma vida feliz e livre do peso do trabalho. Por essas razões, instituições de defesa dos direitos da criança e do adolescente vêm trabalhando, desde o início dos anos 90, na conscientização do uso predatório da força de trabal ho infantil, lutando pela criação de políticas de erradicação e indicando a escola como 0 melhor espaço de socialização das crianças.

$\mathrm{Na}$ tentativa de afastar as crianças do trabal ho e incluí-las na escola, o governo criou políticas públicas como o Programa de E rradicação do Trabal ho Infantil (Peti), a B olsa-Escola e o Salário-Família, enquanto o setor empresarial ligado aos complexos agroindustriais investiu nos Pactos de Erradicação do Trabalho Infantil (Neves, 1999; M arin 2006). Embora haja avanços, as crianças ainda permanecem no mercado de trabalho porque as condições de pobreza e miserabilidade das famílias não foram al teradas; ao contrário, vêm-se agravando ao longo dos anos, em decorrência dos processos de concentração da renda do país. A lém disso, o trabal ho desde tenra idade continua sendo percebido como um valor que dignifica as pessoas e, ao mesmo tempo, afasta as crianças da marginalidade.

Dentre as possibilidades do mercado de trabal ho, a agricultura é um campo de emprego para as meninas. No Estado de Goiás, os órgãos públicos e a imprensa local denunciaram, em diversos momentos, a existência do trabal ho de meninas nas atividades produtivas do tomate, do feijão, da pimenta, da melancia, da laranja, da goiaba, do algodão, do alho, de sementes de pastagem, dentre outras. Esses trabalhos apresentam riscos ergonômicos (postura inadequada e esforço físico excessivo), riscos físicos (exposição às intempéries climáticas), riscos biológicos (picadas por animais peçonhentos), riscos mecânicos (por uso inadequado de ferramentas) e riscos químicos (intoxicação por agrotóxicos) (M inistério do Trabal ho, 1996).

Sobrevivendo em condições precárias, as meninas de I taberaí, objeto deste trabalho, desenvolvem um sentimento de sol idariedade ao drama e expressam-no através da disponibilidade de ajudar seus pais nos trabal hos assalariados. Contudo, através das entrevistas, elas definem a profissão de bóia-fria como pouco 
dignificante, pesada, insalubre, desgastante. $M$ ais do que isso, o trabalho na agricultura é percebido como mais apropriado para os homens porque se é visto como, sujo, perigoso e até grosseiro. Elas têm clareza de que é muito sacrifício para tão pouca remuneração. E, embora as experiências de inserções precárias no trabal ho estejam registradas na memória das sucessivas gerações, as crianças e adolescentes definitivamente não desejam repeti-las.

A ssim, as ocupações das meninas aparecem com maior freqüência nos centros urbanos, mais especificamente como empregadas domésticas e babás. É importante notar que, enquanto os meninos trabal ham como aprendizes nas oficinas mecânicas e elétricas, como engraxates de sapatos ou como vendedores de picolés, sorvetes, balas, sucos, queijo e frutas - atividades consideradas apropriadas aos homens por apresentarem riscos de acidentes, de assal tos e de violências de diversas ordens - , as meninas são encaminhadas para os empregos domésticos, pois, na rua, fatalmente sofreriam humilhações, constrangimentos e violências sexuais.

Desde pequenas, as meninas iniciam 0 aprendizado de tarefas em um processo natural de apropriação de saberes e habilidades, cujo intuito é o de prepará-las para o papel social de futuras cuidadoras do lar. A lém desse aprendizado, o conjunto de tarefas domésticas cotidianamente estabelecido é a col aboração das meninas não só para manter a casa em ordem, mas também para internalizar a socialização do grupo. A ssim, elas vão intercalando serviços domésticos, tarefas escolares, programas da televisão e brincadeiras, num contínuo aprendizado dos saberes necessários para a vida, ao mesmo tempo em que criam senso de responsabilidade para com a família. Em algumas situações, as meninas substituem suas mães nas lidas domésticas e no zelo dos irmãos menores: "Eu fasso [faço] de tudo porque a minha mãe não tá em casa minha mãe trabalha fora. Ela trabal ha na roça e só vem de 15 em 15 dia" (14 anos, 3a série).

A s meninas devem incorporar, na casa dos pais, as habilidades mínimas para apresentaremse como candidatas a um emprego de doméstica, para que, ao consegui-lo, não passem por situa- ções vexatórias por falta de aptidão. Essa trajetória profissional é incorporada pelas famílias de trabalhadores pobres como uma predestinação profissional das mulheres, como indica a seqüência da entrevista:

- Q uais trabal hos você faz em casa?

- Eu ajudo a minha mãe a lavar roupa, fazer comida, arrumar a casa, ol har os meus irmãos.

- Você acha importante esses trabal hos?

- Eu acho melhor do que estar na casa dos outros ou na rua fazendo coisas erradas. Eu acho bem melhor trabalhar em casa. Eu vou aprendendo para, quando eu crescer, arrumar a casa dos outros. A gente acostuma trabal hando e, quando a gente vai trabal har numa casa rica, não quebra nada dos outros, porque tem alguns que ficam vigiando. Se quebrar al guma coisa, descontam no salário da gente.

- Então, você pensa em trabalhar na casa dos outros?

- Uai! Eu penso, né? Todo o mundo tem que trabalhar. Eu acho assim que os pobres têm que trabal har na casa dos outros. Por exemplo, eu vou para o primeiro ano do segundo grau. Eu vou precisar de livros, eu vou ter que trabalhar para ter esses livros porque nem 0 meu pai nem a minha mãe vai dar conta, sabe, porque é muitos irmãos. (13 anos, 8aㅗ série)

Trabalhar como babá é uma outra al ternativa para as meninas e jovens pobres. $N$ as redações, elas fazem um contraponto entre a importância do aprendizado e o peso da responsabilidade de cuidar de filhos dos outros, sobretudo diante dos riscos de acidentes em que as crianças podem envolver-se e das agressões que el as sofrem das próprias crianças. Isso pode ser evidenciado na redação de duas jovens, ambas com 14 anos de idade, estudantes da 7ạ série:

No momento o meu trabalho não é muito bom mas é um trabalho. Eu trabal ho de babá cuido três criança. 0 menino tem 1 ano e 2 meses a menina tem 3 anos e a outra 5 anos. Este trabalho é bom mas também tem os seus problemas como as criança beliscão [beliscam] mordem e batem sabe porque eles tem siumes [ciúmes] um dos outros então descontão [descontam] na gente sabe não estou agentando [agüentando] mais as crianças são teriveis [terríveis]. 
$M$ as este trabalho é importante sabe porque 0 trabalho é fundamental na minha vida sabe porque tenho que trabalha para comprar o que eu gosto.

0 trabalho é importante sim sabe por que sem ele não seria ninguém.

A pesar de os empregos de doméstica e de babá proporcionarem aprendizagem e certa autonomia financeira para suprir as necessidades materiais e simbólicas, o cotidiano na casa das patroas érepleto de dificuldades. Sobrecarga de trabalho, longas jornadas, ausência de descanso semanal, reclamações da qualidade do serviço, humilhações ao receber restos de comida ou roupas usadas e armadilhas para testar 0 caráter são os principais motivos de sofrimentos e constrangimentos, acumulados através das experiências individuais ou coletivas.

A já secular prática de os patrões explorarem não só o trabalho, mas também o corpo das empregadas domésticas, é outro problema, reiteradamente mencionado nas entrevistas. Por essa razão, alguns pais evitam que suas filhas tornem-se empregadas domésticas ou adiam essa situação máximo possível, programando arrumar-Ihes emprego quando já dispuserem dos documentos necessários e estiverem mais preparadas física e emocionalmente para defenderem-se:

Eu nunca trabalhei fora porque a minha mãe fala assim: "Patrão fica olhando a gente, sabe, judiando, fazendo trem com a gente". Aí ela falou: "Não, é melhor você pegar uns 15 ou 16 anos para começar a trabal har fora". 0 meu pai também não aceita eu trabalhar. É que falta muitas coisas dentro de casa. Às vezes meu pai não tem serviço e eu fico doidinha para começar a trabalhar, sabe? Igual o dia que começou as aulas, fazia dois meses que meu pai não trabal hava e não tinha nenhum centavo. Aí eu falei: "Não, eu tenho que trabalhar!" Aí a minha mãe disse: "Como é que você vai trabalhar, com falta de documento? Quem é que vai te pagar? Você tem que trabalhar um mês antes de receber". A í eu me aquietei. Mas eu quero trabalhar para ajudar mais em casa. (14 anos, 8asérie)

Q uando a gente vai arrumar trabal ho, as mães não deixam porque pensam assim: os patrões ficam com safadeza, olhando as meninas.
Q uando a mulher dele sai, fica com sacanagem com a gente, né? $\mathrm{E}$ as mães pensam que vai fazer al guma besteira; é por isso que não deixa. É perigoso, já aconteceu até com minha mãe, quando ela era nova igual a eu. (12 anos, 5a série)

Não se pode, contudo, pensar que as relações entre patroas e empregadas sejam marcadas apenas por conflitos. Entre esses agentes sociais criam-se relações amistosas, com espaços para partilha de objetos, valores, saberes e sentimentos. A oportunidade de continuar os estudos e a oferta de novos referenciais de sociabilidade são aspectos muito valorizados pelas jovens, pois fornecem-Ihes o traquejo necessário para circular por outros espaços sociais, o que normalmente os pais não conseguiriam proporcionar-Ihes. Por essa razão, muitos pais confiam suas filhas às patroas como se estas fossem educadoras que darão continuidade aos ensinamentos recebidos em casa. $\mathrm{Na}$ efetivação do emprego, quase sempre mediada pela mãe ou pelo pai, ressaltam-se os valores morais e religiosos da família, a fim de que as filhas sejam bem aceitas nas casas das patroas e preservadas de constrangimentos maiores. A ssim, sob regras morais, os pais tratam de criar relações de vínculos recíprocos, de respeito e trocas, transformando a patroa numa real benfeitora, capaz de dar outras al ternativas ao círculo limitado de reprodução social (N eves, 1999).

Para as meninas trabalhadoras, 0 ingresso nas atividades produtivas visa satisfazer à necessi dade primeva: a alimentação. Dentro da ordem natural da vida, as pessoas precisam al imentarse para continuar vivendo e, para tanto, devem trabal har para adquirir os recursos mínimos à reprodução física e social. Trabal har éa maneira honesta, digna e eticamente aceitável, para conseguir dinheiro que será trocado por outros bens imprescindíveis à satisfação das necessidades vitais. Se os adul tos assumem o trabal ho como condição humana e sentido de vida, as meninas aprendem e aceitam a fatalidade do destino já dado.

Se não trabalhar ninguém vive. Tem que ajudar nas despesas por que, se não ajudar, como é que vai fazer para tratar da gente, né? A ssim, se a gente não alimenta, não é nada; não pode 
fazer nada. Se a gente não al imentar, não pode viver. (12 anos, 4à série)

Diante das privações, as crianças percebem o trabal ho como uma saída moralmente aceitável para a aquisição dos bens materiais e simbólicos necessários. 0 trabal ho surte, então, um efeito pedagógico na vida das meninas, na medida em que as ensina a valorizar todas as pequenas conquistas obtidas com o próprio esforço físico. Nesse aprendizado, os fil hos passam a reconhecer que os pais enfrentam dificuldades para prover a família e solidarizam-se com a luta dramática pela sobrevivência, assumindo parte do fardo através da "ajuda". Embora apareçam como dependentes, as meninas são estimuladas ao trabalho como parte do aprendizado de saberes e fazeres necessários à vida: trabal hando elas aprendem, ao mesmo tempo em que ganham o próprio sustento. Dessa forma, 0 trabalho entra na ordem natural da vida das meninas como algo que deve ser incorporado na prática cotidiana, no projeto de construção social das futuras trabal hadoras.

Vivendo sob constante suspeita, um resultado da associação naturalizada entre pobreza e marginalidade, as meninas internal izam que a vinculação ao trabalho pode constituir-se na salvaguarda das diversas formas de violência. No caso específico das meninas, os problemas mais temidos são a gravidez precoce, os estupros ea prostituição. No plano do discurso, o trabalho é representado como imprescindível para desenvolver o senso de responsabilidade, disciplina, obediência e honestidade, requisitos estes necessários à formação de trabalhadores honestos. $M$ ais do que isso, o trabal ho atua como contraponto da desordem pessoal e social imanente ao mundo da marginalidade. Por esses motivos, no discurso do senso comum repete-se a idéia de que "é muito melhor trabalhar do que roubar". Sob esse prisma, o trabalho ordena a vida e previne a delinqüência juvenil, como uma espada que separa o bem e 0 mal, 0 certo e 0 errado, o legal e 0 interdito.

Cotidianamente, os pais incutem em seus filhos idéias de reprovação ao que consideram desperdício e luxúria. M ais do que isso, desenvolvem um sentimento de gratidão ao que foi conquistado, mesmo que a quantidade e a qualidade não Ihes sejam satisfatórias, pois na humildade de ol har para trás é possível perceber a existência de pessoas que sofrem privações ainda maiores. Também, na situação de impossibilidade de contar com o mínimo para a sobrevivência, as crianças aprendem a solidarizar-se com os pais, desejando ajudá-los sempre que possível. Nas entrevistas, várias meninas afirmaram ter solicitado a seus pais que fizessem a intermediação para arranjar-Ihes al gum trabalho:

Hoje eu trabalho em casa, mas eu fico louca para trabal har fora. Eu sempre digo: “ $M$ ãe eu quero sair da I grejinha, onde vou todos os dias para fazer minhas tarefas, para começar a trabal har num supermercado ou de serviços de doméstica". Hoje em dia os pais da gente ganham muito pouco e eu quero ajudar. (12 anos, 4aㅡérie)

As meninas sonham com transposição da real idade marcada pela pobreza da família e pela precarização das relações de trabalho em que elas e suas famílias estão inseridas. Para tanto, muitas meninas almejam corresponder às expectativas traçadas pelos adultos se propondo a "aprender a ler e escrever", "aprender a estudar direitinho", "passar de ano", "ter na vida um bom estudo", "aprender muitas coisas", "ser al guém na vida", "ter amigos", "ser amiga de todos da escola", "respeitar os colegas e os adultos", "crescer com educação". N essas expressões, percebe-se que elas desejam internalizar os princípios da socialização do grupo familiar, ressaltando a importância dos estudos, bem como as virtudes e qualidades da pessoa educada, amigável e respeitosa para com os outros.

O s estudos escolares, na visão das meninas, adquirem muita importância na superação dos problemas da desqualificação profissional enfrentados pelos pais de família, cujo acesso ao saber escolar foi nulo ou insuficiente. Em seus depoimentos, são recorrentes os argumentos que ressaltam a importância da escola para fornecer os referenciais necessários à transposição das precárias condições materiais e sociais vivenciadas por suas famílias. Eles depositam muita esperança na escola, pois através dela acreditam que podem alcançar "um futuro melhor", "uma vida digna" e "uma boa profissão", capazes de proporcionar autonomia pes- 
soal e financeira, além do imprescindível reconhecimento social. A ssim, através da escola, esperam obter os trabalhos mais valorizados e bem remunerados, deixando para trás aqueles serviços reservados apenas para os menos capacitados.

M eu pai sempre diz: "Eu quero que vocês estudem para no futuro não ter muito sofrimento. Estudem porque no futuro vocês vão ter um trabalho de advogada, professora. Vai ganhar bem. A gora trabalhar de gari, de bóiafria? Tem que ter um estudo melhor. N ão pode parar, não!". (12 anos, 5aㅗérie)

Em algumas redações, algumas adolescentes, já mães, afirmam que sonham com um bom emprego para dar o que consideram "0 melhor" a seus filhos. E começam a sentir-se impossibilitadas de realizar-se pessoal e profissionalmente. Nesse exercício de mortificação dos próprios sonhos, projetam nos filhos a esperança de uma vida melhor. Os estudos necessários para a qual ificação incompatibilizam-se com as novas exigências, e, devido às despesas com a prole, a incorporação em qualquer trabalho torna-se uma saída premente. V ão-se os sonhos deum futuro melhor efaltam condições objetivas para a transposição das fronteiras da precariedade. Por conseguinte, as jovens terminam repetindo a triste sina de suas mães, marcada pela baixa escolaridade e pela desqualificação profissional, que resulta na pobreza, caprichosamente transferida como legado geração após geração (Neves, 2001; M arques, 2001).

\section{Consider ações finais}

$\mathrm{Na}$ geração das avós, a família era praticamente 0 mundo onde as meninas podiam se mover, o que constituía um dos fatores importantes para a persistência de certos padrões socialmente estabelecidos. A valorização da família e da comunidade, como os principais espaços de transmissão dos conhecimentos requeridos, tornava insignificantes os saberes repassados pela escola, e, com isso, eram raras as meninas que tinham rudimentos de leitura e escrita. Portanto, na instituição familiar, elas forjavam sua própria identidade em referência ao seu model o familiar, particularmente vis-àvis de sua mãe e de suas irmãs mais vel has. As meninas deviam incorporar os trabalhos, os saberes e os comportamentos "apropriados" para o sexo feminino, para logo poderem assumir os papéis sociais das mul heres adul tas. D e certo modo eram vistas como "mulheres pequenas" em processo de aprendizagem na família e, por extensão, na sociedade.

0 processo de modernização da agricultura provocou impactos significativos na vida dos trabalhadores, na medida em que impôs a necessidade de reconstruir suas estratégias de sobrevivência nas periferias das cidades e, não raras vezes, de redefinir os papéis sociais de cada integrante da família, dado o agravamento da pobreza da população migrante. Dentro e fora do espaço doméstico, todas as meninas foram compelidas ao trabalho para contribuir para a manutenção do grupo familiar. 0 deslocamento rural-urbano obrigou o migrante a, progressivamente, reestruturar a sua identidade e a incorporar novos padrões culturais. Contudo, essa mudança não implicou, necessariamente, a destruição dos padrões de cul tura interiorizados no passado. A ssim, as lidas da casa, os trabal hos agrícolas, os cuidados com os irmãos menores e os empregos domésticos continuaram sendo atribuições das meninas, no esforço de instrumentalizá-las para os papéis sociais de produtoras e reprodutoras da força de trabal ho que cabia às mulheres. A socialização das meninas continuou reforçando a sexualização dos papéis e os estereótipos, definidos e compartilhados como próprios das mulheres. 0 treinamento preparativo para a assunção da condição de mulher se estabelecia, especialmente, nas redes de interação com as mulheres mais velhas, seja dentro ou fora do grupo doméstico.

No contexto atual, a institucionalização de políticas públicas buscou proibir o trabalho infantil. Porém, a realidade demonstra que as meninas continuam trabalhando, inicial mente na casa de seus pais, como parte do processo educativo e preparatório das primeiras ocupações laborais e, posteriormente, em casas al heias como empregadas domésticas ou babás. Contudo, o trabalho doméstico infantil não adquiriu visibilidade social no contexto estudado, uma vez 
que é realizado dentro das casas dos patrões e é percebido como algo necessário, natural e edificante. A ssim, as prerrogativas da cidadania garantidas no Estatuto da Criança e do A dolescente não passam de uma ficção jurídica, e as meninas pobres continuam a ser condenadas a processos de exclusão social que se iniciam na infância e se estendem até a vida adulta.

Por fim, nas três diferentes gerações estudadas neste trabalho, a condição feminina aparece como elemento relevante na distribuição e no controle do trabal ho pela família e pela sociedade. $\mathrm{Na}$ família e fora dela, as meninas sempre suportaram o peso da dupla exploração: a primeira decorrente da própria condição de mulher, e a segunda de ser criança ou jovem. 0 fato de serem consideradas "mulheres pequenas" deixava-as total mente indefesas diante dos processos de exploração, uma vez que el as não se constituíam em trabal hadoras de fato, mas "ajudantes" ou "aprendizes" que deviam acatar as ordens das pessoas mais velhas, sob 0 pressuposto de que el as sabiam o que era certo. $\mathrm{N}$ ão se pode ignorar que 0 trabalho das meninas sempre se constituiu em um expediente necessário para a preservação e treinamento da força de trabal ho e obtenção de mão-de-obra praticamente gratuita, que, por conseqüência, retroalimenta o sistema desigual, em termos socioeconômicos. Dessa forma, as trabalhadoras infantis aprenderam - e continuam aprendendo - a sujeitar-se a uma socialização violenta, que as transforma em objetos de interesses al heios, em meros instrumentos de ampliação da riqueza, que não se converte em mel horias de suas condições de vida, nem mesmo de seus familiares.

\footnotetext{
Abstract: This article analyses the inconporation processes of girls in domestic and agriaultural works, based on the experiences of three different generations. The girls' works have always been orientated to the preparation of the woman' s role as a reproducer in the biological, social and economical senses. It comes true that in the successive generations the girls had to face the exploitation of their works due to being children and female.
}

K ey words: gender; children's work; Goiás.

\section{Referências}

ANTUNIASSI, M. H. R. O trabalhador infantil e escolarização no meio rural. Rio de J aneiro: Zahar Editores, 1983.

ARIÈS, P. História social da criança e da família. Rio de J aneiro: LTC, 1981.

BEQUEL, A .; BOY DEN, J . Leenfant au travail. Paris: Fayard, 1990.

BER GER, P. I.; LU CK M AN N, T. A construção social da realidade: tratado de sociologia do conhecimento. Petrópolis: Vozes, 1997.

BONNET, M. Regards sur les enfants travailleurs. La mise au travail des enfants dans le monde contemporain. A nalise et étude de cas. L ausanne: Editions Page D eux, 1998.

BOURDIEU, P. 0 poder simbólico. Rio de J aneiro: B ertrand B rasil, 1998.

D'INCA 0, M . C. 0 bóia-fria: acumulação e miséria. Petrópolis: Vozes, 1975.

GONZALES, E. N.; BASTOS, M. I. O trabalho volante na agricultura brasileira. In: REUNIÃO NACIONAL SOBRE M Ã O-DE-OBRA VOLANTE NA A GRICULTURA , 5. Anais... B otucatu: DECOR/ FCA 1982.

GOUVEIA , A . J 0 trabal ho do menor: necessidade transfigurada em virtude. Cadernos de Pesquisa, São Paulo, v. 44, fev. 1983.

M ACHADO NETO,Z. A s meninas: sobre o trabal ho da criança e do adolescente na família proletária. Ciência e Cultura, v. 32, n. 6, jun. 1980.

MARIN, J. O. B. Crianças do trabalho. Goiânia: Editora da UFG; B rasília: Plano, 2005.

Trabalho infantil: necessidade, valor e exclusão social. Goiânia: Editora da UFG , B rasília: Plano, 2006.

MARQUES, W. E. U. Infâncias (pre)ocupadas: trabalho infantil, família e identidade. B rasília: Plano, 2001.

M A RTIN EZ A LLIER, V. A s mul heres do caminhão de turma. D ebate e Crítica, n. 5, mar. 1975.

M A RTINS, J. S. A valorização da escola eo trabalho no meio rural. In: WERTHEIN, J.; BORDENAVE, J. D. (Orgs.). Educação rural no terceiro mundo: experiências e novas alternativas. Rio de Janeiro: Paz eTerra, 1981.

MENDELIEVICH, E. El trabajo de los niños. Ginebre: OIT, 1980.

MINISTÉRIO DO TRABALHO. Diagnóstico preliminar dos focos do trabalho da criança e do 
adolescente no Brasil. Ministério do Trabalho: B rasília, 1996.

NEVES, D. P. A perversão do trabalho infantil: lógicas sociais e al ternativas de prevenção. Niterói: Intertexto, 1999.

. L a pauvreté comme legs: le travail des enfants dans I' etat de Rio de J aneiro. Études rurales, juilletdecémbre 2001.

NORONHA, M. O. De camponesa a "madame": trabal ho feminino e relações de saber no meio rural. São Paulo: Loyola, 1986.

PAIVA, V. Educação popular e educação de adultos. São Paulo: L oyola, 1987.
PA ULIL 0, M. I. 0 peso do trabalho leve. Ciência Hoje, v. 5, n 28, jan./fev. 1987.

SCHLEM M ER, B. (Dir.). L' enfant exploité: oppression, mise au travail, prolétarisation. Paris: Edition K arthala: Orstom, 1996.

SILVA, M . A . M . Errantes do fim do século. São Paulo: Ed. Unesp, 1999.

SORJ, B. Estado e classes sociais na agricultura. Rio deJ aneiro: Zahar Editores, 1980.

WHITA KER, D. C. A . Escola, violência e trabal ho infantil no B rasil. Perspectivas, São Paulo, n. 12-13, 1990. 